\title{
Faculty opinion on shared authority: A Nigerian national survey*
}

\author{
AGATHA U. ONWUNLI ${ }^{1} \&$ AUGUSTINE O. AGHO ${ }^{2}$ \\ Assistant University Registrar, Florida A\&M University, Tallahassee, Florida 32307, \\ (E-mail: Agatha.Onwunli@famu.edu); ${ }^{2}$ School of Health Professions and Studies, The \\ University of Michigan-Flint, Flint, Michigan 48047 (E-mail: aagho@umflint.edu)
}

\begin{abstract}
The purpose of this paper is to (1) describe the characteristics and governance structure of higher education at the Federal Universities in Nigeria, and (2) examine (a) how academic decisions are made, (b) the level of academic staff participation in university governance, and (c) the extent to which academic staff is consulted on key personnel issues. The results of the investigation revealed that (a) academic staff members believed they are consulted on academic matters through their representatives in the faculty senate, (b) their participation in decisions related to non-academic matters is very limited, (c) academic decisions related to admissions criteria and accreditation standards are made by external bodies, (d) administrators make administrative decisions with very limited input from academic staff (e) compared to lower ranked academic staff members, higher ranked academic staff members perceived the governance process to be very effective, and (f) academic staff members are dissatisfied with the general working conditions and the governance process. Overall, the results of this study strongly suggest the need for improvement in the consultation process, and more involvement of the academic staff in other governance issues especially the selection and appointment of administrators, including Vice-Chancellors.
\end{abstract}

Keywords: consultation, faculty opinion, faculty satisfaction, governance, higher education system in Nigeria, shared authority

Nigeria elected a president for a democratic government in May 1999, after fifteen years of military rule thereby bringing about hope for change, especially for academic staff (faculty members) at the various federal universities. Under the military regime, funding for higher education was neglected. The inadequacy resulted in low faculty moral and satisfaction, lack of library resources, in-hospitable student housing, deplorable classrooms, and overcrowding. It was common for faculty members to go for months without remuneration. The effect of the neglect and inadequate funding of higher education still persist today despite the change in leadership. The present government has embarked on a program to revitalize the higher education system in Nigeria. The receptivity of the academic staff to the initiatives proposed by the new government may depend on their perception of their involvement in the governance process. Faculty participation in decisionmaking or shared authority has never been more significant as the federal 
government tries to restore confidence in the Nigerian populace and the university community in particular.

The purpose of this paper is to (1) describe the characteristics and governance structure of higher education at the Federal Universities in Nigeria, (2) examine how academic decisions are made, (3) examine the level of academic staff participation in university governance, and (4) examine the extent to which academic staff is consulted on key personnel issues.

\section{The conceptual framework}

Shared authority or joint participation is a concept promoted by the American Association of University Professors (AAUP), the American Council on Education (ACE), and the Association of Governing Boards (AGB) to outline what academic governance ought to be in the United States. The concept embodies the idea that there should be joint effort through communication, mutual interests and understanding between the constituents of colleges and universities in decision-making and in the planning of institutional matters. This concept of shared authority has come to be universally accepted (Mortimer and McConnell 1978).

Several studies have described academic staff participation in different settings (Mortimer and McConnell 1978; Dill and Helm 1988; Gilmour 1991; Saltzman and Grenzke 1997) and have observed that making decisions without high degree of academic staff participation may have "deleterious effects on institutional morale and on overall effectiveness" (Dimond 1991, p. 63; Kochan et al. 1986).

The American Association of University Professors describes consultation as "a formal procedure or practice that provides a means for the academic staff to present its judgment in the form of a recommendation or vote in time to affect the decision being made" (Mortimer and McConnell 1978, p. 7).

The conceptual framework of this study was based on the elements of adequate consultation proposed by Mortimer and McConnell (1978). Consultation was defined as the extent to which university administration solicit academic staff input in the decision making process. The authors maintained that in order for consultation to be adequate the following six elements must be present:

a. Academic Staff must be consulted early enough in the process: The principle of early consultation requires that the issues to be discussed are presented in general terms, and that the specific questions the consultation will address be formulated jointly. Consultation, when indicated, should occur early before alternatives are formulated and positions taken. For instance, it is not consultation if the administration asks 
for consultation after deciding or taking a position on a course of action.

b. Procedures for consultation must be formulated jointly: An agreement over how the academic staff should be consulted is a very important step toward the building of trust, which is important in a joint endeavor. The administrators and the consulting body should first agree on the procedures through which the consulting should be conducted.

c. Academic staff should have adequate time to formulate responses: There should be time allowed for the consultants to deliberate over the issues. Requests for advice often have deadlines. This is understandable; however, persistent requests for immediate response may become aggravating and overload an academic staff's capacity to respond thoughtfully.

d. Availability of information: There should be a free flow of information relevant to the issue for consultation. The academic staff should have free access to the available information in order to consider all sides of the issue and present alternatives in their recommendations. However confidentiality may be a source of concern during consultation and deliberation stages. This may restrict the flow of some needed information. Such restriction must be fully justified to avoid misunderstanding.

e. Adequate feedback: After those consulting have rendered advice, there should be adequate response from the administration. Administrators' failure to accept or to immediately implement a recommendation from the consultants does not necessarily mean that the recommendation has been rejected. It is important that the administration meet with the consultants to explain why a report was not accepted or why the recommendations may not be implemented.

f. Communication of the decisions: When decisions are made, they should be adequately communicated to the appropriate academic staff committee.

\section{Significance of the problem}

Nigeria, located in the Sub-Sahara continent of Africa, is the largest and most culturally and ethnically diverse country in Africa. Nigeria gained its political independence from Britain in 1960 and has been plagued with the same political and economic problems faced by many developing countries. Out of 40 years of independence, Nigeria has been ruled by military governments for 26 years. The military governments through decrees and promulgated laws and rules gradually reduced the decision-making authority of the academic staff. As a result, there has been a significant increase in academic staff discontent over governance (West Africa, August 1992) prompting them to 
take several actions ranging from formal letters of complaint addressed to university administration, or the National University Commission (NUC) to boycott of classes and/or outright strikes. These actions always centered on economic factors such as salary structure and pay level, university funding for libraries, funds for research, and their desire to participate in decisions that affect them, the students, and the university.

Recently, Altbach and Lewis (1995) conducted an international study sponsored by the Carnegie Foundation for the Advancement of Teaching in which they examined professorial attitudes in fourteen (14) countries selected from North America, South America, Latin America, Europe, Asia, and the Middle East. On the issue of governance, the authors revealed that faculty members reported (a) a high degree of dissatisfaction with current administrative and governance system, (b) senior faculty are generally more likely to accept decisions made by administrators than junior faculty, (c) they have some influence in academic decisions, (d) they play a very limited role in governance at the institutional level, (e) they are alienated from the higher echelons of administration at their universities and college, (f) they consider lack of involvement in governance as a problem, and (g) perceived the lack of faculty-administration communication as a problem. While the findings of this study have provided insight and contributed to our overall understanding of professorial attitude around the world, the generalizability of the findings may be limited. The countries included in the study are the United States, Brazil, Chile, Mexico, England, Germany, the Netherlands, Russia, Sweden, Hong Kong, Japan, South Korea, Israel, and Australia. Sub-Sahara Africa was one of the geographical region excluded from the study. Given the unique political, economic, social, and cultural characteristics of the Sub-Sahara continent of Africa, it is not clear whether the findings reported by Altbach and Lewis (1995) can be generalized to this region. Specifically, the unique governance of Nigerian higher education suggests a need for a more focused investigation on the attitude of academic staff in Nigeria.

\section{Overview of governance structure of Nigerian higher education system}

The governance of a Nigerian federal university includes the Visitor (the President of the federal government), the National Universities Commission (a governing body), Committee of Vice Chancellors, the University Council, the Senate, Faculty Boards, Departmental Boards, and the Academic Staff Union of Universities. These are briefly discussed below.

The Visitor. All Federal University Acts (or Charter) authorizing the creation of universities have functions reserved for the President of the Country to 
serve in the capacity of a "Visitor". The Visitor is required to visit each federal university at least once a year. For many years the role of the Visitor as stipulated in the Federal Universities Acts, was not expressly followed. In the Report of the Commission on the Review of Higher Education in Nigeria (1992), the Commission recommended that the Visitors role be modified to involve a visitation panel or board to represent the President in an attempt to minimize interference and the appearance of interference from the government. During the military rule the federal government rejected this recommendation (Federal Government of Nigeria 1992, p. 16).

National Universities Commission (NUC). The NUC, established in 1962, serves as an administrative body advising the Federal Government on the financial needs of all Nigerian Universities. A military government decree in 1974 gave the NUC a statutory status and gave it broad powers to coordinate, develop, and make recommendations for university funding, determine "minimum standards for all universities in the federation, and to accredit their degrees and other academic awards" (NUC 1992, p. 26). According to Aderibigbe (1992), this function of accrediting the university programs has become a major and essential function of the NUC.

The several functions of the NUC have drawn criticism from scholars in Nigerian higher education who believe the NUC has marginalized the functions of other academic agencies, and delimited the roles of other governance structures in the universities (Ojo 1990; Ajayi 1983). Ajayi (1983) stated that the NUC's centralized control over the universities has discouraged other alternative decision-making structures such as the Committee of Vice-Chancellors, National Union of Nigerian Students, and Academic Staff Union of Universities.

The Committee of Vice Chancellors $(\mathrm{CVC})$. CVC is an informal coordinating body for joint consultation among universities with no statutory powers (Fafunwa 1992). CVC consists of the Vice-Chancellors of all Nigerian Universities and is modeled after the Vice-Chancellors and Principals of the Universities in Great Britain. According to Taylor (1992) the vice-chancellor of

a ... university in many of the countries influenced by British models, has many responsibilities similar to those of rectors of European universities and presidents of universities and colleges in the United States (p. 1411).

The Vice-Chancellor of a Federal University may be appointed or dismissed by the Visitor after consultation with the University Council. The ViceChancellor is also the chairman of the Senate and all other committees of the Senate and is therefore responsible for providing leadership within the insti- 
tution, promoting the image of the university and also executing the policies of the Senate and Council.

The Vice-Chancellors of Nigerian universities meet to take joint positions on common university problems including student issues, admissions, and library facilities, and function through subcommittees, ad-hoc study groups, working parties, and task forces. They make recommendations to the NUC on academic matters and are at times consulted by the NUC before certain academic decisions are made (Aderibigbe 1992; Williams 1991). Decisions reached by the CVC after considering the recommendations of the various subcommittees are referred to the different university councils or senates for their approval and implementation.

The University Council. The University Council has authority over financial and policy issues with powers to manage and particularly control the property and expenditure of the university (Ojo 1990). This function depends on the approval of the Visitor (University of Ibadan Act S. 4(1) 1962). The vested powers of the various councils in the universities vary according to the University "Charter". The Council is supposed to be responsible for the allocation of funds and to oversee the general policies of each university. These functions are somewhat restricted due to the greater percentage of revenue $(90-95 \%)$ required to run the universities that is furnished by the Federal Government.

The Senate. The University Senate has been identified as a formal structure of academic staff representative governance at the universities (Birnbaum 1989; Ojo 1990). Participation of academic staff in the senate or an advisory committee has been accepted as an essential characteristic of most universities in the United States (Tierney 1991; Berdahl 1989; Rice and Austin 1989). As in American universities, academic staff members participate in governance through faculty senates and/or collective bargaining arrangements.

Full professors at Nigerian Universities are automatically granted membership in the Senate; other members are elected from the various Faculty Boards. Federal University Acts (charters) specify authority for the Senate, with power to "organize and control ... teaching at the university, admission, discipline of students, and promote research" (cited by Ojo 1990, p. 75).

Faculty Board. In Nigerian higher education institutions the "faculty" is a school or college comprising of several departments. A Faculty Board is made up of all the academic staff in the departments that make up a faculty. 
A dean or associate dean presides over meetings. The faculty board discusses such academic matters as admissions, curricula, examination procedures, grading systems, and new course developments. The Faculty Board makes recommendations to the Senate on issues pertaining to appointments, promotions, study leave, sabbaticals, and reappointments (Fafunwa 1992).

Departmental Boards. Departmental boards are made up of all academic staff in the department. The Head of Department presides over the meetings and nominates members to serve on the Faculty Board Committees. Program issues are discussed at this level. The departmental board reports to the Faculty Board through recommendations on academic issues (Fafunwa 1992).

Academic Staff Union of Universities. The Academic Staff Union of Universities (ASUU) is an organization for all academic staff members of the Federal Universities. ASUU is a trade union whose primary goal is to improve the welfare of the academic staff in the universities through their "encouragement of the participation of its members in the affairs of the university system and of the nation ... protection and advancement of the socio-economic and cultural interests of the nation ... (cited by Dimowo 1991).

In recent years, ASUU concerned itself with the issue of institutional funding, university autonomy and academic freedom. This concern led to several banishments and reinstatements of ASUU since 1988 (Onwunli 1998). After several strikes and numerous negotiations, a welfare package was signed between ASUU and a federal government negotiation team (September 3, 1992). The package contained agreements on the ASUU demands for university autonomy, adequate funding and enhanced conditions of service (fringe benefits) for the academic staff of Nigerian universities ("The Gains" 1992). ASUU has affected decision-making on campuses indirectly, and its influence on recent developments has been noteworthy.

The Joint Admissions and Matriculation Board (JAMB). JAMB was established in 1978 to solve the then identified problems of multiple applications for admissions, entrance examinations and multiple admissions to the various universities. Prior to the establishment of JAMB there were very few universities and few slots for students. It was observed that some applicants gained admissions to more than one university thereby denying others a chance for university education.

The Joint Admissions and Matriculation Board (JAMB) control the admission of all undergraduates in all the Federal Universities in Nigeria. It prepares and administers the admission examination and compiles the results. 
However, Departmental Boards, Faculty Boards and the Senate make the actual choice of candidates to admit under strict JAMB guidelines. JAMB, then, makes the final decisions and issues admission letters to candidates. In essence, the academic staff on the above mentioned boards and committees merely carry out JAMB policies as JAMB conducts entrance examinations and places qualified candidates to the institutions. JAMB, however, has since experienced serious problems ranging from examination leakages, cheating, computer manipulations, and delays in placing candidates.

It is evident from the above descriptions that the governance structure of the Nigerian federal universities is designed to encourage participative form of governance except for the establishment of the NUC and JAMB which have served as controlling agencies.

\section{Current situation of higher education in Nigeria}

In May 1999, Nigeria elected a president for a democratic government after fifteen years of military rule. The new government, five months after it was instituted, articulated a policy of "creating a conducive environment for teaching, learning and research" for its universities. There are indications widely reported in newspaper and government reports that the newly elected democratic government is poised to take steps needed to implement substantive changes. While the efforts may be applauded, the tactics are questionable.

The new democratic government created a visitation panel representing the President. Among the first recommendations made by the visitation panel were the dismissal of some Vice Chancellors and the dissolution of the governing councils (see Table 1) of 18 federal universities (Emerole 1999). The appointment of VCs has been politicized in the past, and ethnic considerations for appointments have led to unrests and disruptive behaviors by students (Post Express Oct. 18 1999).

The December 1999 arbitrary dismissal of some VCs of federal universities was done without consultation with the academic staff or university bodies. This was not only discouraging but also defied democratic principles. Apart from funding issues, the appointment of a VC to a university has been the main avenue of governmental interference at the universities. The $\mathrm{VC}$ has the primary responsibility of determining the direction of the university and therefore influences the nature of governance at the university. Arbitrary decision to appoint a $\mathrm{VC}$ to a university invariably influences the governance direction of the institution.

As part of the 1992 agreement reached between academic staff of Nigerian universities and the federal government, the universities were to appointment 
VCs based on established implementation plans. Two Federal Universities implemented a version of the steps for the appointment of the VC. The process was welcomed and deemed successful by the academic staff of these universities and the system as a whole. At the time of data collection for this study, the University of Jos was in its selection stage for a VC and academic staff was involved in the selection process at every stage. However, in January 2000, Student Union Government of the Federal University of Port Harcourt protested what they termed the "imposition of an acting Vice-Chancellor" on the university. The appointment of the university Vice-Chancellor was done against the established and articulated procedures (Post Express Jan. 17 2000). Although the new government, as part of its commitment to provide "conducive environment" for teaching and learning, has delegated the responsibility of the selection and appointment of VCs on the university communities, the implementation and effectiveness of the commitment is yet to be realized.

Under the military rule, the functions of some formal structures of authority at the federal universities were practically limited. For example, the establishment of the National Universities Commission (NUC), the Joint Admissions and Matriculation Board (JAMB), and other such bodies severely reduced the powers of the university council and the academic senate. On several occasions the Federal Government disciplined students without consulting university authorities and instructed University Council to dismiss some academic staff without due process or regard for existing contracts (Ojo 1990). It is not clear if the new democratic government will re-define the functions of JAMB.

On May 22nd 2000, the Federal Ministry of Education introduced a bill to "grant (federal) universities the freedom and autonomy to function as an independent entity". The bill proposes that appointment of vice-chancellors will be carried out by the university through the governing council; the National Universities Commission (NUC) will be restructured to reduce its level of control over the universities; and universities will be granted "selfmanagement and financial deregulation" to allow flexibility (Guardian, May 22 , 2000). The meaning and definition of autonomy has spurred several discussions, debates and conferences as the universities try to work with the new government. Recently, a former Vice Chancellor of the University of Ibadan (Professor Ayo Bayo) stated that "no autonomy could be realized until the government left the composition of the Council members in the hands of a Board of Trustees" in order to deflect the influence of the government (Guardian March 13, 2000), implying that federal government still influences the "composition" of the university council. 
However, a more serious condition exists as both parties consider institutional autonomy differently. While some university administrators see autonomy as their ability to teach, serve, and conduct research within the scope of the mission of the institutions with funding received from federal government but without interference on administration; the federal government representatives see institutional autonomy as the university's ability to run its own business without funding from the government.

The present attempts to make changes have not been re-assuring to the faculty members. The federal government has embarked on a series of talks with the Academic Staff Union of Universities (ASUU) over such issues as university funding, institutional autonomy, salary and improved conditions of service for academic staff in the federal universities. The 1992 welfare package agreement between ASUU and the federal government is yet to be fully implemented. ASUU officials have threatened and embarked on strikes and boycotts as recently as May 2003 (Vanguard, May 20th 2003).

They have been promised changes that would perhaps placate the university constituents and minimize the influences of external constituents. At this time, it is important to restore academic confidence in the collegiate way of doing things.

\section{Method}

Sample

The study population consisted of all the academic staff employed in the Nigerian federal universities. According to the 1991 National Universities Commission Annual report, 8,203 academic staff members were employed at the 21 established federal universities (the three newly established universities of agriculture were excluded). A headcount of 7,792 academic staff was obtained from the publication of the Commonwealth Universities Yearbook 1992, which listed the names, ranks and departments of academic staff in the federal universities. Administrators, department heads, part-time academic staff members, and those on leave of absence were excluded. A multi-stage sampling procedure (Babbie 1992) was used to select three universities from each of the three regions of the country, for a total of nine (9) universities. (See Table 1 for the list of the participating university.)

The next step in the sample selection process involved the random selection of 701 academic staff to participate in the study. Self-administered questionnaires were delivered in a batch to the identified coordinators at the universities under study. Five hundred and eighty eight (588) completed survey instruments were received, and 575 were used in the analyses. The 
Table 1. List of Federal universities

\begin{tabular}{|c|c|}
\hline Federal university & Year founded \\
\hline 1. Abubakar Tafawa Balewa, Bauchi* & 1988 \\
\hline 2. Ahmadu Bello Univ. Zaria* & 1962 \\
\hline 3. Bayero University, Kano* & 1977 \\
\hline 4. Federal University of Technology, Akure* & 1981 \\
\hline 5. Federal University of Technology, Minna & 1983 \\
\hline 6. Federal University of Technology, Owerri* & 1980 \\
\hline 7. Federal University of Technology, Yola* & 1980 \\
\hline 8. Obafemi Awolowo University, Ile-Ife ${ }^{*}$ & 1962 \\
\hline 9. University of Abuja* & 1988 \\
\hline 10. University of Agriculture, Abeokuta* & 1988 \\
\hline 11. University of Agriculture, Makurdi & 1988 \\
\hline 12. University of Agriculture, Umudike* & 1988 \\
\hline 13. University of Benin, Benin & 1970 \\
\hline 14. University of Calabar* & 1975 \\
\hline 15. University of Ibadan* & 1962 \\
\hline 16. University of Ilorin* & 1975 \\
\hline 17. University of Jos, Jos* & 1975 \\
\hline 18. University of Lagos* & 1962 \\
\hline 19. University of Maiduguri & 1975 \\
\hline 20. University of Nigeria, Nsukka* & 1960 \\
\hline 21. University of Port-Harcourt* & 1975 \\
\hline 22. University of Uyo, Uyo & 1983 \\
\hline 23. Usman Danfodio University, Sokoto* & 1975 \\
\hline 24. Nigerian Defence Academy & 1964 \\
\hline
\end{tabular}

*Note: The Councils of these universities were arbitrarily dismissed (Emerole 1999). Universities in italics participated in the study.

Source: Based on information from the Commonwealth Universities Yearbook (1992) and Educational Services Counseling Center: Directory of Nigerian Universities (1999).

adequacy of the sample was assessed using the formula developed by Krejcie and Morgan (1970, pp. 607-610). It was determined that the sample size was adequate and the sample was representative of the population. It was also determined that the response rate of $84 \%$ obtained for this study was adequate.

\section{Measures}

Based on the Mortimer and McConnell (1978) conceptual framework, multiple-item scales were developed to measure the six variables (i.e., partici- 
pation in governance, attitude toward governance, perceived effectiveness of staff participation in governance, control, satisfaction with governance system, and consultation) considered in this study. Participation in university governance was measured using 3-items developed for this study. Respondents were asked to indicate "yes" or "no" to questions such as "Have you ever served in a formal governance structure", Have you participated in the election of academic staff representatives", and "Do you attend departmental/ faculty board academic staff meetings." These items yielded a reliability coefficient of 0.67 .

Academic staff attitude toward participation in governance was measured using 15-items developed for this study. Respondents were asked to use a 4-point scale ranging from "strongly agree" to "strongly disagree" to indicate the extent to which they agree with statements such as "Academic staff participation in governance may lead to greater understanding", and "Academic staff participation in governance may provide opportunities for resolving conflicts in cases of divergent objectives." The reliability coefficient for this scale was 0.79 .

Perceived effectiveness of academic staff participation was assessed by (a) asking respondents to indicate whether they usually influence the decisionmaking process "formally", "informally", or "formally and informally", and (b) by asking respondents to use a 4-point scale ranging from "very effective" to "not effective" to indicate their response to a question regarding how effective is the present academic staff participation in the governance process. The test-retest reliability coefficient for this item was 0.87 .

Control over academic and personnel issues was measured by presenting respondents with nine academic issues and seven personnel issues and asked to indicate whether decisions over these issues are made (a) entirely by academic staff, (b) entirely by administrators, (c) jointly by academic staff and administrators, or (d) not sure. The test-retest reliability coefficient for the Items was 0.84 .

Satisfaction with governance system was measured with a single-item 4point scale which required respondents to indicate the extent to which they agree or disagree with a statement regarding how satisfied they were with the process.

Consultation, defined as the extent to which university administration solicit academic staff input in the decision making process, was measured with the "adequate consultation" scale developed by Mortimer and McConnell (1978). For this study, the six-item scale yielded an alpha coefficient of 0.87 . 
An open-ended question was designed to solicit the respondent's views on changes that can be made to improve the governance and consultation process.

Analysis

Descriptive statistics (e.g. means, range, and frequencies), chi-square analyses, t-test, and Analysis of Variance (ANOVA) were computed using the Statistical Packages for Social Sciences (SPSS). ANOVA was determined to be appropriate because the independent variables consisted of nominal or categorical data. The validity and reliability of the measurements were assessed by using these methods: (1) factor analysis, (2) expert review of clarity, readability, relevance, and appropriateness of questionnaire items, (3) a test-retest method, and (4) computation of Cronbach Alpha. Content analysis technique was used to summarize the respondents' responses to the open-ended question.

\section{Results}

\section{Demographic characteristics}

Of the 575 respondents, 449 were males and 126 females; 17 were bachelor degree holders, 207 held Masters degrees, 351 doctoral degrees; 326 earned their highest degree from a Nigerian University and 249 earned their highest degree from a foreign university (See Table 2 for demographic information.) With regards to length of service at the university, 30.3 percent had been employed at the university for less than five years, 27.5 percent had 6-10 years of service, 22.3 percent had 11-15 years of service, and 20 percent had over 16 years of service. In terms of academic rank, 9.7 percent were Assistant Lecturer, 39.1 percent were Lecturer I or II, 34.3 percent were Senior Lecturer, 5.2 percent were Associate Professor, 10.1 percent held the rank of Professor and 1.6 percent did not specify any rank. The department/disciplines represented in the study included Arts and Sciences (41.4 percent), Medicine (12.2 percent), Law (2.8 percent), Engineering (5.7 percent), Agriculture (8.7 percent), Education (16.0 percent), and Business (12.5 percent).

\section{Active participation in governance}

Seventy-eight percent of the respondents reported they have served in formal governance structures, ninety percent have participated in elections, eightthree percent reported that they attend meetings regularly, and fifty-one 
Table 2. Demographic information about respondents $(\mathrm{n}=575)$

\begin{tabular}{|c|c|}
\hline Variables & $\begin{array}{l}\text { Percent } \\
\text { respondents }\end{array}$ \\
\hline \multicolumn{2}{|l|}{ Length of service } \\
\hline $0-5$ & 30.3 \\
\hline $6-10$ & 27.5 \\
\hline $11-15$ & 22.3 \\
\hline 16 and over & 20.0 \\
\hline \multicolumn{2}{|l|}{ Rank } \\
\hline Assistant Lecturer & 9.7 \\
\hline Lecturer I or II & 39.1 \\
\hline Senior Lecturer & 34.3 \\
\hline Associate Professor & 5.2 \\
\hline Professor & 10.1 \\
\hline Other & 1.6 \\
\hline \multicolumn{2}{|l|}{ Department/discipline } \\
\hline Arts and Sciences & 41.4 \\
\hline Medicine & 12.2 \\
\hline Law & 2.8 \\
\hline Engineering & 5.7 \\
\hline Agriculture & 8.7 \\
\hline Education & 16.0 \\
\hline Business & 12.5 \\
\hline Other & 0.3 \\
\hline \multicolumn{2}{|l|}{ Gender } \\
\hline Male & 78.1 \\
\hline Female & 21.4 \\
\hline \multicolumn{2}{|l|}{ (Missing = 3 responses) } \\
\hline \multicolumn{2}{|l|}{ Highest degree earned } \\
\hline Bachelor's & 2.6 \\
\hline Master's & 35.0 \\
\hline Doctorate & 61.4 \\
\hline Other & 1.0 \\
\hline \multicolumn{2}{|c|}{ Where highest degree was obtained } \\
\hline Nigerian University & 56.7 \\
\hline Univ. outside Nigeria & 43.1 \\
\hline (Missing = 1 response) & \\
\hline
\end{tabular}


percent reported that they have served in an administrative capacity. Respondents with more than 16 years of service reported more active participation than those with less years of service (chi-square 11.36; $\mathrm{df}=3.571 ; p=$ 0.0001 ). Gender differences in governance participation were not found to be statistically significant. Respondents who were former administrators indicated more participation in governance than those who had never held such positions $(t$-value $=8.71 ; p=0.001)$.

\section{Attitude toward participation}

Fifteen statements were used to measure the academic staff member's attitudes toward participation in governance. The average mean rating for the sample was 3.42 on a four-point scale. As shown on Table 3, respondents reported a high level of positive attitude toward governance. They agreed that academic staff participation may lead to greater understanding, promote cooperation and coordination, and provide opportunities for resolving conflicts in cases of divergent objectives between administrators and academic staff. No statistically significant differences were observed among the universities in terms of location, year of establishment, gender, or previously held administrative position. Respondents with more than 16 years of service reported more positive attitude toward participation in governance than those with less years of service (chi-square 5.19; $\mathrm{df}=3.569 ; p=$ $0.0015)$.

\section{Perceived effectiveness of academic staff participation}

In response to the questions designed to assess the respondents' perceived effectiveness of academic staff participation in governance, only 54.4 percent indicated that academic staff participation was effective, 74.1 percent reported that they influenced decision-making on campus formally through senate, 10 percent reported they influenced decisions informally, and 15 percent indicated they influenced decisions both formally and informally. Compared to those employed at universities established in the 1970s and 1980s, respondents employed at the universities established in the 1960s reported that academic staff participation in governance is effective in terms of influencing academic decisions (chi-square $=4.02 ; \mathrm{df}=2.572 ; p=0.0184$ ). Respondents with more than 16 years of service reported that academic staff participation in governance is effective more so than those with less years of service (chi-square $=3.16 ; \mathrm{df}=3.571 ; p=0.0241$ ). Respondents who were former administrators responded more favorably to this question than those who have never held such position ( $t$-value $=9.34 ; p=0.001$ ). No statistically significant difference in the responses of female and male respondents was observed. 
Table 3. Mean ratings on attitude toward participation

\begin{tabular}{|c|c|c|c|}
\hline Items & Range & Mean & St. dev. \\
\hline \multicolumn{4}{|l|}{ Academic staff participation, may: } \\
\hline 1. Lead to a greater under-standing & $1-4$ & 3.73 & 0.551 \\
\hline $\begin{array}{l}\text { 2. Academic staff participation may make it difficult to assign } \\
\text { responsibilities for successes, or assign blames for failures }\end{array}$ & $1-4$ & 3.22 & 0.757 \\
\hline $\begin{array}{l}\text { 3. Be time consuming thereby introducing delay when } \\
\text { immediate decision is needed }\end{array}$ & $1-4$ & 3.22 & 0.757 \\
\hline $\begin{array}{l}\text { 4. Promote cooperation and coordination between } \\
\text { administration and academic staff }\end{array}$ & $1-4$ & 3.56 & 0.553 \\
\hline $\begin{array}{l}\text { 5. Provide opportunities for resolving conflicts in cases of } \\
\text { divergent objectives }\end{array}$ & $1-4$ & 3.50 & 0.544 \\
\hline $\begin{array}{l}\text { 6. Allow the use of the expertise of the academic staff on } \\
\text { the issues }\end{array}$ & $1-4$ & 3.62 & 0.528 \\
\hline 7. Satisfy academic staff's need for autonomy & $1-4$ & 3.24 & 0.803 \\
\hline 8. Lead to acceptance and/or implementation of decisions & $1-4$ & 3.30 & 0.596 \\
\hline 9. Result in an administrative leader being viewed as weak & $1-4$ & 3.42 & 0.698 \\
\hline 10. Not be necessary for effective institutional governance & $1-4$ & 3.52 & 0.651 \\
\hline \multicolumn{4}{|l|}{$\begin{array}{l}\text { Rationale for academic staff participation includes the } \\
\text { following: }\end{array}$} \\
\hline 11. Academic staff expertise on the issues/subjects & $1-4$ & 3.35 & 0.664 \\
\hline $\begin{array}{l}\text { 12. Academic staff's interests are at stake when only the } \\
\text { administrators make campus decisions }\end{array}$ & $1-4$ & 2.97 & 0.889 \\
\hline $\begin{array}{l}\text { 13. Academic staff's cooperation is essential to the effective- } \\
\text { ness of a campus }\end{array}$ & $1-4$ & 3.46 & 0.561 \\
\hline $\begin{array}{l}\text { 14. Academic staff efforts create and sustain institutional } \\
\text { activities }\end{array}$ & $1-4$ & 3.41 & 0.578 \\
\hline $\begin{array}{l}\text { 15. None of the above rationale. Academic staff should not be } \\
\text { involved in campus decision making }\end{array}$ & $1-4$ & 3.80 & 0.576 \\
\hline
\end{tabular}

Note: High scale value indicate positive attitude.

\section{Control over academic and personnel issues}

The responses to the questions regarding control over academic and personnel matters are presented on Table 4. As can be seen, academic decisions related to determining course content, setting degree requirements, establishing programs, reviewing programs, and setting research standards and policies 
Table 4. Control over academic and personnel decisions $(\mathrm{n}=575)$

\begin{tabular}{lrrrr}
\hline \multirow{2}{*}{ Items } & \multicolumn{4}{l}{ Percentage of respondents* } \\
\cline { 2 - 5 } & \multicolumn{1}{l}{ 1 } & \multicolumn{1}{c}{3} & \multicolumn{1}{c}{4} \\
\hline Academic decisions & & & & \\
Setting admissions policies & 37.4 & 12.2 & 42.3 & 8.2 \\
Determining course content & 85.2 & 3.1 & 9.4 & 2.3 \\
Setting student-faculty ratios & 21.0 & 25.0 & 38.3 & 15.7 \\
Setting degree requirements & 73.6 & 3.3 & 19.3 & 3.7 \\
Establishing undergraduate prog. & 59.5 & 12.5 & 24.3 & 3.7 \\
Establishing graduate programs & 65.2 & 10.3 & 20.7 & 3.7 \\
Reviewing/discontinuing programs & 54.3 & 12.7 & 27.7 & 5.4 \\
Set research standards and policies & 66.1 & 4.9 & 19.7 & 9.2 \\
Accept research funds & 34.1 & 12.0 & 39.0 & 15.0 \\
Personnel decisions & & & & \\
Appointing Vice-Chancellors & 23.1 & 13.4 & 48.9 & 14.6 \\
Appointing department heads & 37.7 & 35.8 & 21.0 & 5.4 \\
Hiring new academic staff & 27.8 & 12.3 & 56.3 & 3.5 \\
Grant academic staff promotions & 34.1 & 9.9 & 53.4 & 2.6 \\
Determining salary schedules & 6.4 & 37.7 & 42.4 & 12.9 \\
Policies about outside income & 10.8 & 30.1 & 37.6 & 21.6 \\
Adjudicate grievances & 18.1 & 13.2 & 58.3 & 10.4 \\
\hline
\end{tabular}

*Where: 1 = decision made entirely by academic staff; $2=$ decision made entirely by the administrators; 3 = decision made jointly by academic staff and administrators; $4=$ not sure about who makes the decision.

are made mostly by academic staff. Decisions made by administrators with minimal consultation with academic staff include appointing the Vice Chancellor, hiring a new academic staff, granting promotions, determining salary schedule, and setting policies about outside income.

\section{Satisfaction with governance process}

Seventy-four percent of the academic staff members reported that they were not satisfied; and 26 percent indicated that they were satisfied with their level of involvement in the governance process. Satisfaction did not vary by gender, or length of service. Respondents who were former administrators reported higher level of satisfaction with the governance $(t$-value $=6.23 ; p=0.001)$. 
University administration consultation with academic staff

Academic staff views regarding how the consultation process should be structured is presented on Table 5. The mean scores ranged from 3.36 to 3.66, with an average score of 3.54. Respondents strongly agreed with the statements that (1) they should be consulted early in the deliberation of issues, (2) procedures should be jointly formulated, (3) adequate time should be allowed to enable them formulate responses, (4) information should be made available to them, (5) adequate feedback should be provided, and (6) that final decisions should be communicated to them. When asked to describe the actual practice of consultation in their respective universities, 45.2 percent indicated that they were consulted after positions and/or minds were made up on the issues, 10.3 percent indicated that they were consulted after decisions had been made, 11.3 percent indicated they were not consulted at all, and 33 percent indicated that they were consulted early enough in the decision making process.

The results of the ANOVA test revealed that respondents employed at universities established in the 1970s and 1980s believed that they were consulted after decisions are made (chi-square $=5.55 \mathrm{df}=3.571 ; p=0.0002$ ). Compared to those with fewer years of service, respondents with more than 16 years of service viewed the consultation process to be adequate (chi-square $=6.55 ; \mathrm{df}=3.571 ; p=0.0002)$. Respondents who were former administrators viewed the consultation process more favorably than those who have never held such position $(t$-value $=4.73 ; p=0.001)$. No statistically significant difference in the response of female and male respondents was observed.

\section{"Desired changes" suggested by academic staff}

The academic staff members were asked to suggest what changes they would like to make to improve the governance and consultation process. Of the 575 respondents, 274 noted desirable changes in the following areas: more academic staff involvement in the selection of Vice Chancellors; establishment of a rational consultation process; creation of a forum for discussion and exchange between academic staff and administrators; increased participation of junior faculty in the governance and strategic planning process; and less government interference.

\section{Summary and conclusion}

The results of the investigation revealed that (a) academic staff members believed that they are consulted on academic matters through their representatives in the faculty senate, (b) academic staff participation in decisions 
Table 5. Mean rating of adequate consultation process

\begin{tabular}{llll}
\hline Items & Range & Mean & Std. dev. \\
\hline 1. Acad. Staff should be consulted & $1-4$ & 3.58 & 0.572 \\
2. There should be an agreement over procedures & $1-4$ & 3.34 & 0.716 \\
3. Allow adequate time for deliberation & $1-4$ & 3.61 & 0.564 \\
4. There should be free flow of information & $1-4$ & 3.65 & 0.520 \\
5. Administrators should explain actions taken on & $1-4$ & 3.41 & 0.690 \\
recommendations & & & \\
6. Decisions made should be adequately communicated & $1-4$ & 3.66 & 0.522 \\
\hline
\end{tabular}

Note: High value indicates agreement with the elements of adequate consultation.

related to non-academic matters is very limited, (c) academic decisions related to admissions criteria and accreditation standards are made by external bodies, (d) administrative decisions are made by administrators with very limited input from academic staff members, (e) compared to lower ranked academic staff members, higher ranked academic staff members perceived the governance process to be very effective, and (f) academic staff members are generally dissatisfied with the general working conditions and the university governance process. Overall, the results of this study strongly suggest the need for (1) improvement in the consultation process, (2) improvement of the relationship between the academic staff and the administrators, and (3) more involvement of the academic staff in other governance issues especially the selection and appointment of administrators including ViceChancellors.

These findings are consistent with the results obtained by Altbach and Lewis (1995). Using a large data set consisting of academic staff from Europe, South America, North America, Asia, and the Middle East, the authors found a high degree of dissatisfaction among academic staff. Interestingly, senior academic staff was also found in this study to be generally more satisfied with the existing administrative and governance system. Based on the findings of the present study, it is apparent that the level of satisfaction among academic staff is low and there is a strong desire among academic staff to be consulted on academic matters and to be more involved in the decision making process. University administrators can address these issues by taking proactive measures necessary to facilitate inputs from academic staff. Other specific measures may include:

(1) Allowing academic staff members to be actively involved in the selection and evaluation of university administrators, especially the Vice Chancellor and department heads; 
(2) Improving the relationship and communication between academic staff representatives and the academic staff;

(3) Developing a process to regularly monitor faculty satisfaction with governance process;

(4) Developing a better working relationship between the National Universities Commission (NUC) and the Federal universities;

(5) Restructuring the composition of faculty senate to include all academic staff members, and restructuring the governance system for one that may be suitable for all the universities. University Acts or By-laws, which formally exclude some university constituents from the decision-making process, may be reviewed; and

(6) Creating an atmosphere where academic staff and university administrators can freely exchange information on academic, curriculum, and personnel matters. An atmosphere where there is a consensus on the procedures and conditions by which administrators and academic staff consults with each other should be fostered.

The feasibility and effectiveness of these policy recommendations may depend on the extent to which the federal government, National Universities Commission, Committee of Vice Chancellors, the University Council, Faculty Senates, Faculty Boards, Departmental Boards, and the Academic Staff Union of Universities can develop a shared vision on the value of academic freedom and shared governance.

\section{Recommendations for further studies}

Six suggestions are advanced for future research in this area. First, given that perceptions and situations of 'mood and affect' are subject to change over time, a longitudinal approach may be a better method of assessing academic staff attitude toward shared authority and governance in Nigerian Federal Universities. Second, this study did not investigate differences in the perception of previous and current administrators on the effectiveness of cogovernance. It is conceivable that the views of those who are presently serving in administrative capacities may vary from those who have had the privilege of serving in such capacities in previous years. It is suggested that a future study should specifically examine and differentiate the opinion and attitude of former administrators and current administrators towards co-governance and co-consultation. Third, this study should be replicated to examine the extent to which satisfaction with faculty governance vary by academic discipline, salary, rank, and level of education. Fourth, a field research design should be explored to conduct a thorough investigation of the attitude of faculty towards shared governance and the impact of faculty dissatisfaction with 
governance on productivity and turnover. Rather than focusing on all federal universities, the field study approach may require the investigator to select one university from each region of the country in order to ensure adequate sample representation, thus increasing the generalizability of the findings. Fifth, the extent to which academic staff expectations, perception of academic freedom, and attitude towards shared governance vary by the dominant political system is worthy of investigation. In other words, do academic staff members in countries where national leaders are democratically elected have different orientation and attitude towards the value of academic freedom and shared governance than those expressed by academic staff in non-democratic countries. Finally, this study did not compare and contrast the views of the Committee of Vice Chancellors and academic staff members on the value and effectiveness of shared authority. This should be considered in future studies on this subject.

\section{Acknowledgement}

The authors will like to thank Dr. Francis Ngwaba, Professor of English, Abia State University, Nigeria, for his constructive critique of the first draft of the manuscript.

\section{Note}

* This report is partly based on the first author's dissertation submitted to the College of Education, Florida State University, Tallahassee, Florida. Direct all inquiries to the first author

\section{References}

Aderibigbe, A. (1992). 'The universities in Nigeria' The Commonwealth Universities Yearbook 3, 2449-2452.

Agreement between the Federal Government of Nigeria and the Academic Staff of Nigerian Universities (September 3, 1992). Lagos, Nigeria.

Ajayi, A. (1983). 'Planning and co-ordination in a federal system: The evolution of the Nigerian University system', in Chinelo, A. (ed.), Twenty Years of University Education in Nigeria. Lagos, Nigeria: National Universities Commission.

Altbach, P. and Lewis, L. (1995). 'Professorial attitudes - An international survey', Change (Nov.-Dec.) 27(6), 50-57.

American Association for Higher Education (1967). Faculty Participation in Academic Governance, A Report of the AAHE-NEA Task Force on Faculty Representation and Academic Negotiations. Washington DC: Campus Governance Program. 
Babbie, E. (1992). The Practice of Social Research. Belmont, California: Wadsworth Publishing Company.

Berdahl, R. (1989). 'Shared governance and external constraints', in Peterson, M. (ed.), Organization and Governance in Higher Education. Needham Heights, Massachusetts: Ginn Press. (Reprinted from Governing Tomorrow's Campus (1989). Macmillan).

Birnbaum, R. (1989). 'The latent organizational functions of the academic senate', Journal of Higher Education 60(4) 423-442.

Dill, D. and Helm, K. (1988) 'Faculty participation in strategic policy making', in Smart, J. (ed.), Higher Education Handbook of Theory and Research, Vol. IV. AIR and ASHE New York: Agathon Press, pp. 319-355.

Dimond, J. (1991). 'Faculty involvement in institutional budgeting', New Directions for Higher Education 75, 63-78.

Dimowo, F. (1991). 'Staff unions and management in the Nigerian university system', A Speech Delivered at the 14th Annual Committee of Vice-Chancellors of Nigerian Universities Seminar held at the University of Benin.

Emerole, J. (1999), 'FG dissolves governing councils of 18 varsities: Vice-chancellors to go', Post Express Wired (December 17).

Fafunwa, A. (1992). 'Nigeria', in Clark, B. and Neave, G. (eds.), Encyclopedia of Higher Education: Vol. 1. National Systems of Higher Education. Oxford: Pergamon Press, pp. 514-524.

The Gains of ASUU (1992, September 21). News Watch, p. 14.

Gilmour, J. (1991). 'Participative governance bodies in higher education: Report of a national study', New Directions for Higher Education (Fall) (No. 75) 19(3), 27-39.

Kochan, Katz and McKersie, (1986). 'The transformation of American industrial relations', cited by Salzman, G. and Grenzke, J. (1997). 'Faculty and staff look at their roles in governance', The NEA Higher Education Journal.

Krejcie, R. and Morgan, D. (1970). 'Determining sample size for research activities', Educational and Psychological Measurement 30, 607-610.

Mortimer, K. and McConnell, T. (1978). Sharing Authority Effectively: Participation, Interaction, and Discretion. San Francisco: Jossey-Bass.

Ojo, J.D. (1990). Law and university administration in Nigeria. Lagos, Nigeria: Malthouse Press.

Onwunli, A. (1998). 'Effect of resource dependence on the cultural values of an academic profession', International Education (Spring).

Rice, E. and Austin, A. (1985). 'High faculty morale: What exemplary colleges do right', Change, 20(2), 50-58.

Salzman, G. and Grenzke, J. (1997). 'Faculty and staff look at their roles in governance'. The NEA Higher Education Journal.

Taylor, W. (1992). 'Leadership: University vice-chancellors', in Clark, B. and Neave, G. (eds.), The Encyclopedia of Higher Education: Vol. 2 Analytical Perspectives. Oxford: Pergamon Press.

Tierney, W. (1991). 'Organizational culture in higher education: Defining the essentials', in Peterson, M. Chaffee E. and White, T. (eds.), Organization and Governance in Higher Education. Needham Heights, Massachusetts: Ginn Press, pp. 126-139.

Williams, G. (1991). 'Funding the university system', A Speech Delivered at the 14th Annual Committee of Vice-Chancellors of Nigerian Universities Seminar held at the University of Benin. 